\title{
Development of Serological Procedures for Rapid and Reliable Detection of Wheat Streak Mosaic Virus in a Single Wheat Curl Mite
}

\author{
T. Mahmood and G. L. Hein, University of Nebraska, Panhandle Research and Extension Center, 4502 Avenue I, \\ Scottsbluff 69361; and R. C. French, Department of Plant Pathology, University of Nebraska, Lincoln 68583
}

\begin{abstract}
Mahmood, T., Hein, G. L., and French, R. C. 1997. Development of serological procedures for rapid and reliable detection of wheat streak mosaic virus in a single wheat curl mite. Plant Dis. $81: 250-253$.

Wheat streak mosaic virus (WSMV) is transmitted by the wheat curl mite (WCM), Aceria tosichella. Immunofluorescent and dot-immunobinding assays were developed to detect the presence of WSMV in single WCM. Virus-specific immunofluorescent microscopy detected WSMV near the anterior end of viruliferous WCM. With dot-immunobinding assay, WSMV was detected in WCM fed on WSMV-infected wheat (Triticum aestivum) but not in WCM maintained on healthy plants. Both immunofluorescent and dot-immunobinding assays were sufficiently sensitive to detect WSMV in individual WCM, providing a means to determine the percentage of viruliferous WCM in field collections.
\end{abstract}

Wheat streak mosaic is an important disease of wheat (Triticum aestivum L.) in the Great Plains of the United States, Canada, and many other wheat-producing countries (3). Regional epiphytotics of the disease have occurred in Colorado, Idaho, Kansas, Nebraska, North and South Dakota, Montana, and Washington. The most serious losses (up to $100 \%$ ) occur when winter wheat becomes infected in the fall (19). Plants may be severely stunted, with varying degrees of necrosis resulting in death of tillers, reduced seed set, and shriveled kernels $(10,11)$. Wheat streak mosaic is caused by wheat streak mosaic virus (WSMV), a potyvirus with filamentous particles, about $700 \mathrm{~nm}$ long and 15 nm diameter (3).

WSMV is specifically transmitted by the wheat curl mite (WCM). Originally named Aceria tulipae Keifer (18), this WCM has recently been renamed Aceria tosichella Keifer (1). WSMV infections are most severe when volunteer wheat results from the shattering of seed heads by hail (19). Volunteer wheat plants are rapidly infested with WCM and serve as a green bridge allowing WCM and the virus to successfully survive the summer. WCM then in-

Corresponding author: Gary L. Hein

E-mail: entm008@unlvm.unl.edu

Present address of T. Mahmood: Texas Agricultural Experiment Station, Texas A\&M University, P.O. Drawer 10, Bushland 79012.

Published as Journal Series Paper No. 11629, Nebraska Agricultural Research Division.

Accepted for publication 12 November 1996.

Publication no. D-1997-0116-08R

(C) 1997 The American Phytopathological Society fest newly planted wheat in the fall. The role of late-emerging volunteer wheat and other alternate hosts in WSMV epidemiology is not well understood. Thus, it is important to predict the potential for WSMV transmission from such plants and to identify the proportion of WCM in a population carrying WSMV.

The importance of the WCM as a vector of WSMV stimulated a number of studies on the relationship between the WCM and the WSMV. Transmission assays have been used to identify viruliferous mites from field and greenhouse populations (12). Virus also was detected in the homogenates of WCM through manual inoculation of wheat leaves or by employing a serological precipitin-ring test (13). Electron microscopy has also been used to test for the presence of virus in WCM (20). However, all of these assay methods required several hundred WCM, and given the small size of the WCM $(250 \times 75 \mu \mathrm{m} ; 7)$, such tests can be cumbersome and time-consuming.

Recently, several adaptations and improvements were made for the detection of plant viruses (22). However, some of the more sensitive assays, such as enzymelinked immunosorbent assay (ELISA), require a minimum amount of test sample to partially fill the microtiter plate wells. The volume of a single WCM is less than 1 $\mathrm{nl}$. The 100 - to $200-\mu \mathrm{l}$ test sample volume used in ELISA represents a 100,000- to 200,000 -fold dilution of the sample. Dotimmunobinding assay and immunofluorescent microscopy may avoid these problems. Immunofluorescent microscopy has been used to detect different plant viruses in individual insects, such as rice dwarf virus and wound-tumor virus in the leafhopper vector $(8,9)$. A direct immunofluorescent antibody labeling technique was used to detect WSMV in crude homogenates from 10 WCM reared on virus-infected wheat (17). Dot-immunobinding assays have been used to detect a variety of plant viruses, such as members of carlavirus, potexvirus, potyvirus (including WSMV), tobamovirus, and nepovirus groups $(2,14,15,16)$, from plant tissue. These dot-immunobinding assays used plant tissue for virus detection. There is to date no report of detection of a plant virus in an insect vector by dot-immunobinding assay. In this paper, we report the results of two serological assays, immunofluorescent microscopy and dot-immunobinding assays, to detect WSMV in single WCM.

\section{MATERIALS AND METHODS}

Virus culture. The Sidney isolate of WSMV (5) was used in this research. The virus was maintained on greenhouse-grown wheat cv. Michigan Amber with frequent transfers. An extract of infected plants was prepared by grinding leaves with a mortar and pestle at a 1:10 dilution (wt/vol) in $0.02 \mathrm{M}$ potassium phosphate buffer, $\mathrm{pH}$ 7.2. Seven to 10 days after planting, test plants were lightly dusted with Carborundum (600 grit), and the wheat (cv. Arapahoe) leaves were rub-inoculated with the extract. Inoculated plants were maintained in the greenhouse for 3 weeks under natural light conditions with a temperature range of 18 to $27^{\circ} \mathrm{C}$.

Virus purification. WSMV was maintained in winter wheat cv. Michigan Amber and purified according to Brakke and Ball (4). Virus was extracted from five to six fully expanded leaves that were infected with WSMV for 2 to 3 weeks. The extract was prepared by grinding the leaves in a blender in $1 \mathrm{mg}$ per $\mathrm{ml}$ of $0.01 \mathrm{M} \mathrm{K}_{2} \mathrm{HPO}_{4}$. The extract was subjected to one cycle of differential centrifugation (low speed $12,000 \times g$ for $15 \mathrm{~min}$ and high speed $60,000 \times g$ for $90 \mathrm{~min}$ ). The pellets were resuspended in $0.01 \mathrm{M}$ citrate buffer, $\mathrm{pH}$ 8.0. The resuspended pellets were clarified by centrifugation at $7,000 \times g$ for $5 \mathrm{~min}$ at $4^{\circ} \mathrm{C}$. The supernatant was further purified by sucrose density gradient centrifugation at $60,000 \times g$ for $3 \mathrm{~h}$. Gradients were fractionated at $254 \mathrm{~nm}$ with an ISCO (Instrumentation Specialties Co., Lincoln, NE) density gradient fractionator. Virus concentration was estimated by ultraviolet absorbance spectroscopy using an extinction coefficient of $3 \mathrm{~cm}^{2} / \mathrm{mg}$ at 254 $\mathrm{nm}(4)$. 
Wheat curl mites. A colony of aviruliferous WCM was started by transferring WCM eggs onto virus-free wheat seedlings with a single hair cemented to a small dowel. All WCM observations and manipulations were done with a stereoscopic microscope. The WCM colony was maintained on healthy wheat (cv. Arapahoe) plants in a growth chamber at $20^{\circ} \mathrm{C}$ for 13 $\mathrm{h}$ days and $14^{\circ} \mathrm{C}$ for 11 -h nights. Care was taken to isolate the WCM colony from potential sources of WSMV contamination.

Viruliferous WCM were obtained by manually inoculating two- to three-leaf wheat plants with WSMV, Sidney isolate. Two weeks after inoculation, when symptoms were evident, aviruliferous WCM were transferred to the WSMV-infected plants. Transfer was accomplished by attaching excised WCM-infested leaves to the infected plants. WCM crawled from excised to attached leaves within 36 to 48 $\mathrm{h}$, after which the excised leaves were removed. WCM were allowed to feed on WSMV-infected plants for a minimum of 1 week before being used in this study.

Field samples of WCM were collected from symptomatic wheat from commercial plantings at three different locations in western Nebraska. These WCM were tested for the presence of WSMV.

Indirect immunofluorescent microscopy. Samples were prepared by placing individual WCM in a grid pattern on glass slides coated with poly-L-lysine (Sigma Chemical Co., St. Louis, MO). Aviruliferous and viruliferous WCM were placed on separate glass slides. The WCM were gently pressed in place with a glass slide. This allowed the WCM to better adhere to the glass and forced internal fluids out. All of these procedures were done while examining WCM under a stereoscopic microscope. WCM were fixed with $2 \%$ paraformaldehyde by submerging slides for $2 \mathrm{~h}$ at $4^{\circ} \mathrm{C}$, and then were washed three times with phosphate-buffered saline (PBS; 145 $\mathrm{mM} \mathrm{NaCl}$ and $10 \mathrm{mM}$ sodium phosphate, $\mathrm{pH}$ 7.2) with $0.1 \%$ Tween 20 (PBS-T). In some experiments, the WCM were fixed with $95 \%$ ethanol rather than paraformaldehyde to test the effectiveness of fixation. WCM were incubated for $2 \mathrm{~h}$ at room temperature with anti-WSMV rabbit immunoglobulin $\mathrm{G}, 1.3 \mathrm{mg} / \mathrm{ml}$, diluted 1:1,000 in PBS-T buffer. The anti-WSMV rabbit immunoglobulin $\mathrm{G}$ was prepared against Sidney isolate of WSMV (supplied by R. C. Gergerich). The slides were washed three times for $10 \mathrm{~min}$ in PBS-T buffer, followed by incubation for $2 \mathrm{~h}$ at room temperature in fluorescein isothiocynateconjugated anti-rabbit serum (Sigma), $1.1 \mathrm{mg} / \mathrm{ml}$, diluted $1: 100$ in PBS buffer. After washing with PBS-T buffer, WCM were examined under an epifluorescent microscope (Nikon Optiphot, Melville, NY) using a fluorescein filter cube (illumination at 450 to $490 \mathrm{~nm}$ ). Aviruliferous WCM were used as negative control. The experiment was performed three times.

Dot-immunobinding assay. A single WCM was crushed and ground with a glass rod in a porcelain spot plate with 10 to 15 $\mu \mathrm{l}$ of Tris-buffered saline (TBS; $50 \mathrm{mM}$ Tris- $\mathrm{HCl}$ and $150 \mathrm{mM} \mathrm{NaCl}, \mathrm{pH} 7.5$ ) while being examined under a stereoscopic microscope. The extract from a single WCM was then serially diluted by five fivefold dilutions to determine the sensitivity of the assay. This dot-immunobinding assay was similar to the procedure of Towbin et al. (21). All steps were performed at room temperature. A nitrocellulose membrane $(15 \times 10 \mathrm{~cm}$, pore size $0.45 \mu \mathrm{m}$; Bio-Rad, Richmond, CA) was marked with a grid of 1.0-cm squares with a no. 2 lead pencil. The membrane was cut to a size that would accommodate the number of samples in an individual test and was immersed in TBS buffer, $\mathrm{pH} 7.5$, for $15 \mathrm{~min}$ by inserting one edge of the membrane into the buffer and allowing it to absorb the liquid by wick action. It then was dried on filter paper for $10 \mathrm{~min}$. Three $\mu \mathrm{l}$ of the sample was placed in the center of each square of the nitrocellulose membrane and allowed to air-dry for $10 \mathrm{~min}$. After blocking with $5 \%$ nonfat dry milk for $2 \mathrm{~h}$ in TBS- $0.1 \%$ Tween buffer, pH 7.5 (TBS-T), it was incubated for $2 \mathrm{~h}$ in anti-WSMV antibodies, 1.3 $\mathrm{mg} / \mathrm{ml}$, diluted $1: 1,000$ in TBS-T buffer. The antiserum used was the same as that
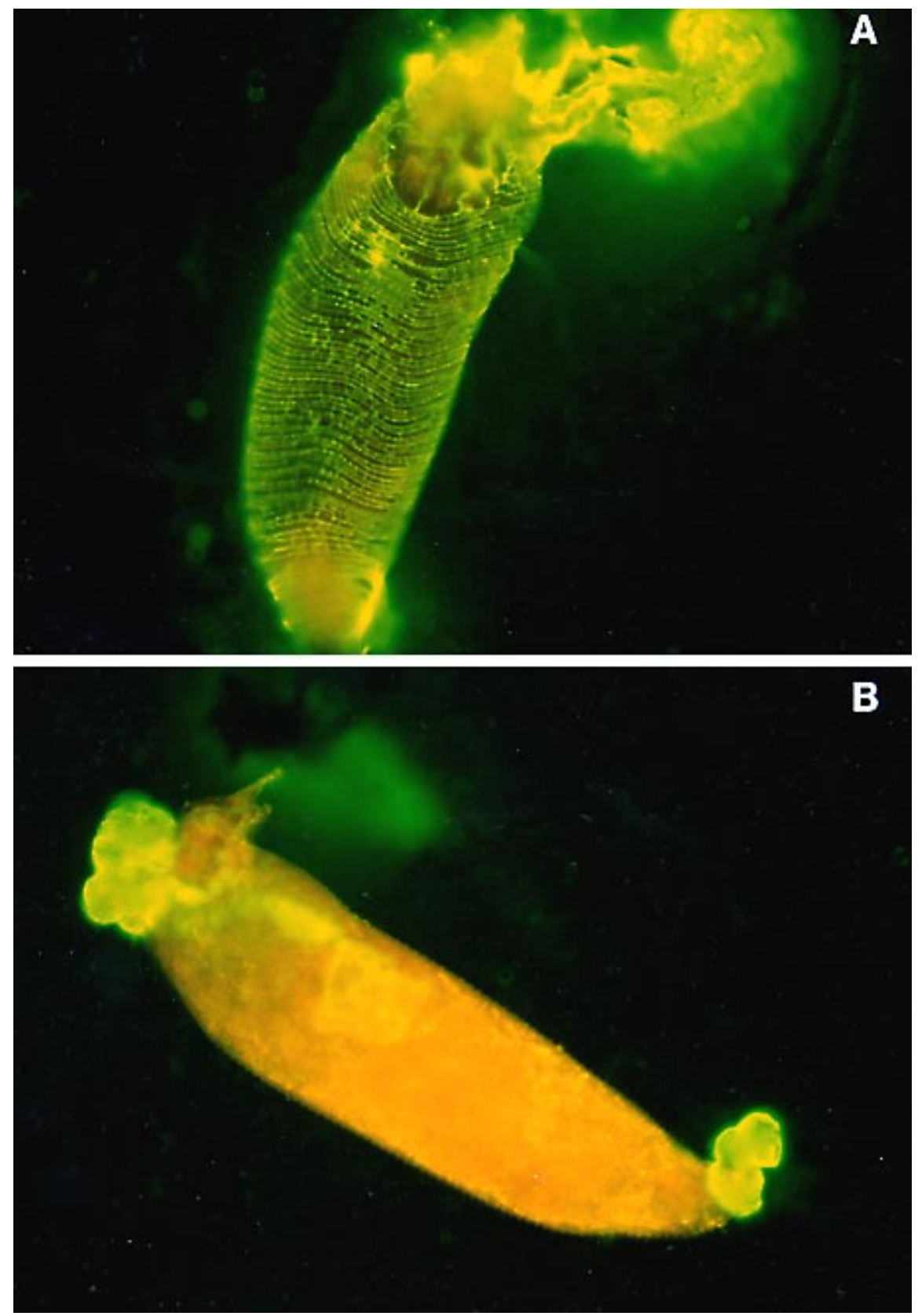

Fig. 1. Indirect fluorescent antibody detection of wheat streak mosaic virus (WSMV) antigen in wheat curl mites (WCM), Aceria tosichella. Detection of WSMV antigen in the body of a single WCM that (A) had fed on a WSMV-infected wheat plant, and (B) had fed on a healthy wheat plant. 
used for the indirect immunofluorescent microscopy. The membrane then was washed three times for $10 \mathrm{~min}$ each in TBS-T buffer and incubated for $2 \mathrm{~h}$ in a $1: 3,000 \mathrm{vol} / \mathrm{vol}(0.8 \mathrm{mg} / \mathrm{ml})$ solution of anti-rabbit antibody conjugated to alkaline phosphatase (Sigma) in TBS-T buffer, $\mathrm{pH}$ 7.5. After washing, the presence of alkaline phosphatase was demonstrated by reacting the membranes with bromochloroindolyl phosphate/nitro blue tetrazolium substrate for $20 \mathrm{~min}$. Aviruliferous WCM were used as a negative control, while purified WSMV was used as positive control. Three $\mu \mathrm{l}$ of a dilution series of a purified virus preparation was used to test the sensitivity of the assay. The experiment was performed three times.

Indirect immunofluorescent microscopy. Preliminary experiments using viruliferous and aviruliferous WCM established the optimum dilutions of first and second antibodies needed in subsequent immunofluorescence assays. Different dilutions of first $(1: 250,500,1,000,2,000)$ and second $(1: 50,100,200,400,800)$ antibodies were tested. Satisfactory results were obtained with a 1:1,000 dilution of first and a 1:100 of second antibodies. In three experiments, 50 WCM from WSMVinfected wheat and $50 \mathrm{WCM}$ from healthy wheat were subjected to indirect immunofluorescent labeling and then were examined microscopically using epiillumination. All WCM examined showed a bright yellow autofluorescence. However, all viruliferous WCM showed an additional brilliant apple-green fluorescence due to specifically bound fluorescein-labeled antibodies.

\section{RESULTS}

This fluorescence was most consistently seen along the body of the WCM (Fig. 1A). However, virus-specific fluorescence was also present at the anterior and posterior ends of some of the viruliferous WCM. This was probably caused by internal fluids squeezed out of the mouth and anus during slide preparation. Aviruliferous WCM never exhibited green fluorescence staining on the sides of the body (Fig. 1B), in contrast to viruliferous WCM (Fig. 1A). The extruded fluid at the anterior ends of some aviruliferous WCM showed a very weak nonspecific fluorescent staining (Fig. 1B), probably caused by the presence of low levels of antibodies to plant sap components in the WSMV antiserum. In contrast to aviruliferous WCM, the fluorescein staining of viruliferous WCM usually quenched or reduced the yellow autofluorescence, facilitating the differentiation of viruliferous and aviruliferous WCM. Samples could be stored at $4^{\circ} \mathrm{C}$ for 2 to 3 weeks without losing their antigenicity. Identical results were obtained with WCM fixed in either $2 \%$ paraformaldehyde or $95 \%$ ethanol.

Dot-immunobinding assay. Virus concentrations from 1 to $5 \mathrm{ng}$ of WSMV per $\mathrm{ml}$ could be detected with the standard dotimmunobinding procedure described (Fig. 2). WSMV was also detected by spotting a $3-\mu l$ aliquot of a homogenate prepared by grinding a single viruliferous WCM in 10 $\mu \mathrm{l}$ of buffer (Fig. 2). WSMV could be detected in homogenate extract of a single WCM after a 1:125 dilution. No background reaction product was seen when extracts of aviruliferous mites were similarly assayed. The samples prepared after grinding WCM could be stored at $4^{\circ} \mathrm{C}$ for

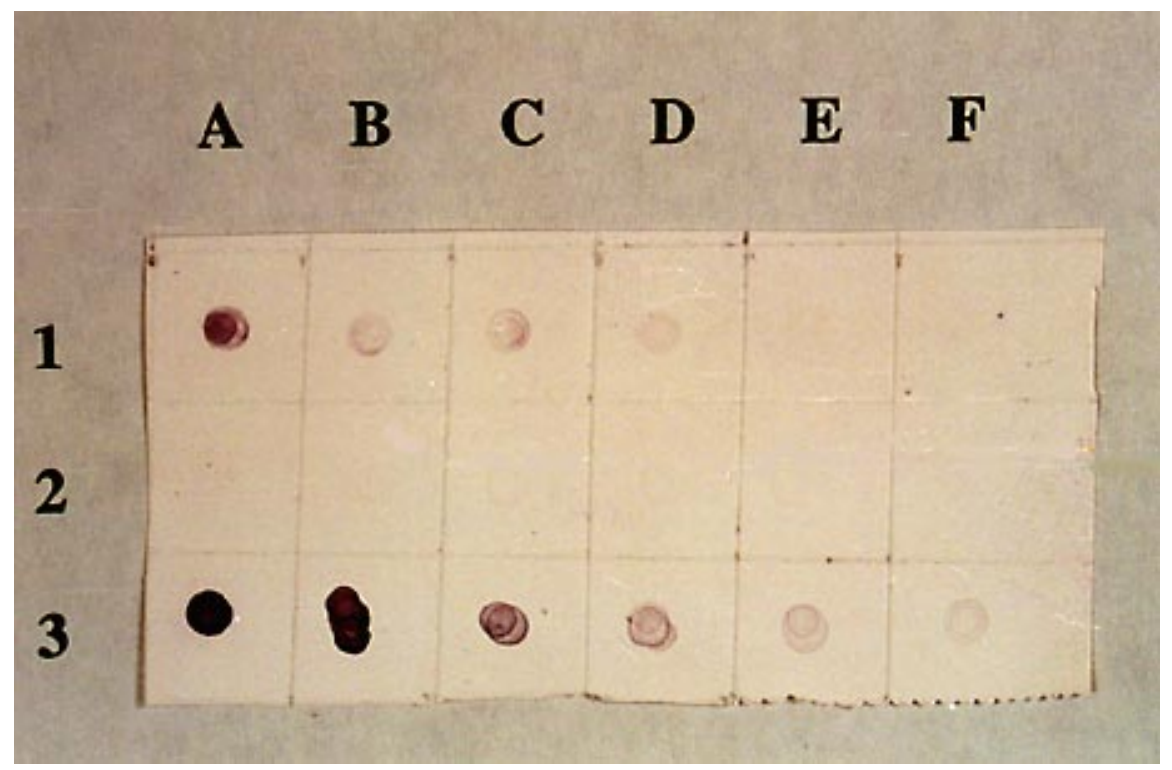

Fig. 2. Dot-immunobinding detection of wheat streak mosaic virus (WSMV). (Row 1) fivefold dilutions of an extract from a single viruliferous wheat curl mite (WCM); (row 2) dilutions of an extract from an aviruliferous WCM; and (row 3) purified WSMV. The concentrations of purified WSMV used were: (A) 5,000 ng/ml, (B) 1,000 ng/ml, (C) $200 \mathrm{ng} / \mathrm{ml}$, (D) $40 \mathrm{ng} / \mathrm{ml}$, (E) $8 \mathrm{ng} / \mathrm{ml}$, and (F) 1 $\mathrm{ng} / \mathrm{ml}$.
2 to 3 weeks without losing their antigenicity.

This procedure was also used to detect WSMV in single WCM collected from symptomatic wheat from commercial plantings. In four different experiments, 21 out of 54 WCM tested positive for WSMV (Table 1). Aviruliferous WCM maintained on healthy wheat were used as a negative control. No aviruliferous WCM tested positive for WSMV.

\section{DISCUSSION}

Immunofluorescent microscopy and dotimmunobinding assays were effective in detecting viruliferous WCM obtained from WSMV-infected wheat and field-collected WCM. The most important criteria in evaluating diagnostic techniques are reliability, sensitivity, and cost. The immunofluorescence assay is more convenient for examining large numbers of mites, but it does require a microscope with fluorescence optics. Thus, the dot-immunobinding assay provides an alternative for laboratories without access to such a microscope. There was some nonspecific staining in immunofluorescent microscopy but very little background with dot-immunobinding assay. This is likely due to differences between the blocking steps used in the two procedures.

Dot-immunobinding assays are valuable because they are simple, sensitive, rapid, and economical. ELISA, especially the double antibody sandwich form (6), has been the method of choice for the detection and assay of plant viruses because it is sufficiently sensitive for most applications. Dot-immunobinding assays and fluorescent microscopy procedures have sensitivity similar to ELISA but produce results that are more difficult to quantify. Dot-immunobinding assays are potentially useful research and diagnostic tools in plant pathology, particularly in the study of pathogens transmitted by eriophyid mite vectors. The low volume of the sample required for dot-immunobinding assays is an important advantage over ELISA in analyzing samples without dilution.

Our results are similar to the work of Sinha and Paliwal (17), who could detect WSMV antigens in crude homogenates

Table 1. Dot-immunobinding assays for wheat streak mosaic virus (WSMV) in samples of wheat curl mites (WCM) collected from symptomatic wheat from commercial plantings

\begin{tabular}{ccc}
\hline Experiment & $\begin{array}{c}\text { WSMV } \\
\text { positive }\end{array}$ & $\begin{array}{c}\text { WSMV } \\
\text { negative }\end{array}$ \\
\hline $1^{\mathrm{a}}$ & 4 & 8 \\
$2^{\mathrm{b}}$ & 5 & 7 \\
$3^{\mathrm{c}}$ & 7 & 7 \\
$4^{\mathrm{c}}$ & 5 & 9 \\
\hline
\end{tabular}

a WCM collected from Kimball County, NE.

${ }^{\mathrm{b}}$ WCM collected from Cheyenne County, NE.

c Two collections of WCM from Scotts Bluff County, NE. 
prepared from WCM from virus-infected wheat plants by using direct immunofluorescent microscopy assays. In their work, WSMV was detected only in the body fluid released through the anus of mites. Our results showed that WSMV was detected in the body fluid released through the anus and the mouth of the WCM. Moreover, WSMV was also detected from both sides of the bodies of mites. This suggests that indirect immunofluorescent microscopy is more sensitive in detecting the presence of WSMV in single WCM.

These assays provide useful tools for virus detection in virus vectors, especially very small vectors, and we have successfully applied these techniques to field-collected WCM. Future investigations need to determine the correlation between the presence of WSMV in WCM populations and the ability of that WCM population to transmit WSMV. It should now be feasible to develop appropriate field sampling methods for testing large numbers of WCM. The proportion of viruliferous WCM in WCM populations on various hosts has hitherto not been examined closely because of difficulties with virus assays on single WCM. The ability to readily identify proportions of viruliferous individuals in WCM populations may allow more effective epidemiological disease transmission models to be developed.

\section{ACKNOWLEDGMENTS}

We thank S. Quisenberry, S. G. Jensen, and M. A. C. Langham for critical reading of the manuscript. We thank R. C. Gergerich for the antiserum.

\section{LITERATURE CITED}

1. Amrine, J. W., Jr., and Stasny, T. A. 1994. Catalog of Eriophyoidea (Acarina: Prostig-mata) of the World. Indira Publishing Co., West Bloomfield, MI.

2. Banttarri, E. E., and Goodwin, P. H. 1985. Detection of potato viruses $\mathrm{S}, \mathrm{X}$, and $\mathrm{Y}$ by enzyme-linked immunosorbent assay on nitrocellulose membranes (Dot-ELISA). Plant Dis. 69:202-205.

3. Brakke, M. K. 1971. Wheat streak mosaic virus. No. 48. CMI/AAB Description of Plant Viruses, No. 48. Commonw. Mycol. Inst./ Assoc. Appl. Biol., Kew, England.

4. Brakke, M. K., and Ball, E. M. 1968. Purification and antigenicity of wheat streak mosaic virus. Phytopathology 58:963-971.

5. Brakke, M. K., Skopp, R. N., and Lane, L. C. 1990. Degradation of wheat streak mosaic virus capsid protein during leaf senescence. Phytopathology 80:1401-1405.

6. Clark, M. F., and Adams, A. N. 1977. Characteristics of the microplate method of enzyme-linked immunosorbent assay for the detection of plant viruses. J. Gen. Virol. 34:475-483.

7. Keifer, H. H. 1938. Eriophyid studies. Calif. Dep. Agric. Bull. 27:181-206.

8. Kimura, I. 1986. A study of rice dwarf virus in vector cell monolayers by fluorescent antibody focus counting. J. Gen. Virol. 67:2119-2124.

9. Kimura, T., and Black, L. M. 1971. Some factors affecting infectivity assays of woundtumor virus on cell monolayers from an insect vector. Virology 46:266-276.

10. McKinney, H. H., Brakke, K. M., Ball, M. E., and Staples, R. 1966. Wheat streak mosaic virus in the Ohio Valley. Plant Dis. Rep. 50:951-953.

11. Niblett, C. L., Heyne, G. E., King, L. C., and Livers, W. R. 1974. Controlling wheat streak mosaic. Kans. Agric. Exp. Stn. AES-7.

12. Orlob, G. 1966. Feeding and transmission characteristics of Aceria tulipae Keifer as vector of wheat streak mosaic virus. Phytopathol. Z. 55:218-238.

13. Paliwal, Y. C., and Slykhuis, J. T. 1967. Localization of wheat streak mosaic virus in the alimentary canal of the vector Aceria tulipae Keifer. Virology 32:344-353.

14. Parent, J. G., Belanger, F., Desjardin, S., and Barisson, J. D. 1985. Dot immunobinding for detection of tomato mosaic virus and potato virus $\mathrm{X}$ infecting greenhouse tomatoes. Phytoprotection 66:53-57.

15. Powell, C. A. 1987. Detection of three plant viruses by dot-immunobinding assay. Phytopathology 77:306-309.

16. Sherwood, J. L. 1987. Comparison of a filter paper immunobinding assay, western blotting and an enzyme linked immunosorbent assay for the detection of wheat streak mosaic virus. J. Phytopathol. 118:68-75.

17. Sinha, R. C., and Paliwal, Y. C. 1977. Detection of wheat streak mosaic virus antigens in vector mites with fluorescent antibodies Phytopathology 67:570-572.

18. Slykhuis, J. T. 1955. Aceria tulipae Keifer (Acarina: Eriophyidae) in relation to the spread of wheat streak mosaic. Phytopathology 45:116-128.

19. Staples, R., and Allington, W. B. 1956. Streak mosaic of wheat in Nebraska and its control Nebr. Agric. Exp. Stn. Res. Bull. 178.

20. Takalnashi, Y., and Orlob, B. 1969. Distribution of wheat streak mosaic virus in Aceria tulipae. Virology 38:230-240.

21. Towbin, H. T., Staehelin, T., and Gordon, J. 1979. Electrophoretic transfer of proteins from polyacrylamide gels to nitrocellulose sheets: Procedures and some applications. Proc. Nat. Acad. Sci. USA 76:4350-4354.

22. Van Regenmortel, M. H. V. 1982. Serology and immunochemistry of plant viruses. Academic Press, New York. 